\title{
Endothelial Progenitor Cells (EPCs) - clinical implications
}

\author{
Arnon Blum ${ }^{1 *}$ and Nava Blum ${ }^{2}$ \\ ${ }^{1}$ Faculty of Medicine in the Galilee Bar Ilan University Israel, Israel \\ ${ }^{2}$ Max Stern Academic College in Emek Israel, Israel
}

\section{Preface}

The endothelium is responsible for the homeostasis of the cardiovascular system and other organs by producing and secreting molecular signals, activating and upgrading expression of receptors on many cell surfaces including endothelial cells themselves, a selfperpetuating condition that is accelerating with time until a specific mechanism blocks the signals. Most of the endothelial progenitor cells (EPCs) reside in niches within the bone marrow and are released only "on demand" when a certain trigger is activated - like ischemia or an increase in oxidative radicals or other inflammatory trigger is activated - recruiting them to remote areas of ischemia where they are most needed for regeneration of blood vessels. By mobilization cells from their niches the regenerative system can create new blood vessels - angiogenesis or vasculogenesis.

\section{Primary endothelial cells}

Angiogenesis is a process involved with stem cells mobilization and building new vessels coming out of an existing blood vessels [1]. Vasculogenesis is a process of building new blood vessels, de novo, from endothelial stem cells and endothelial progenitor cells [2]. This process starts as a colony of primary cells (angioblasts) in the margins of the core composed of hematopoietic cells in the center [3]. Both cells have common characteristics like genetic markers fetal liver kinase (Flk-1), tyrosine kinase with immunoglobulin-like and EGF-like domains 1 (Tie-2) and cluster of differentiation (CD)34. The common belief is that all these cells originate from the same ancient common "father" $[3,4]$.

Hematopoietic stem cells in the peripheral blood are circulating stem cells that were detached from their niches in the bone marrow [5]. Asahara found that the marker CD34 is expressed on all hematopoietic stem cells but it disappears when these cells mature and become defined cells [6,7]. The same phenomenon was described for the receptor of vascular endothelial growth factor - Flk-1 - that characterizes hematopoietic stem cells and primary endothelial stem cells, but disappears during the hematopoietic differentiation and maturation process [8].

When endothelial stem cells marked as $\mathrm{CD} 34^{+}$were grown in culture they became spindle shaped cells within 4 weeks [9]. When cultured on fibronectin coated plates the differentiation into spindle shaped cells occurred within 3 days, and they were attached to the bottom of the plate [9]. CD34 cells were not attached to the bottom of the plate and started to attach to the fibronectin plate only after 4 weeks [9]. interestingly, when both cells were grown together CD $34^{+}$ proliferated extensively and formed tube formation earlier [6]. The combined growth of $\mathrm{CD} 34^{-}$and $\mathrm{CD} 34^{+}$cells created colonies within 12 hours, most of them were composed of $\mathrm{CD} 34^{+}$marked cells, and were characterized by a core shaped island composed of rounded small cells and around this core were spindle shaped cells that surrounded the core like a "sunflower". These structures looked like epiblasts that is known to be the origin of endothelial cells and blood vessels [3].

It appears that during the maturation and differentiation process cell surface markers change. For example, $\mathrm{CD} 34^{+}$cells that were grown on fibronectin $94 \%$ had also a CD $45^{+}$marker that disappeared after 7 days. Only $16 \%$ of cells that started as $\mathrm{CD} 34^{+}$remained with this surface marker after maturation. $27 \%$ developed Flk- $1^{+}$markers, $11 \%$ developed $\mathrm{CD} 34^{+} / \mathrm{Flk}^{+} 1^{+}$cells. Endothelial cell markers like E selectin, Tie-2, Flk-1, CD31, and CD34 were more prevalent among cells that were adherent and stick to the bottom of the plates [6]. These cells secrete nitric oxide in response to acetyl choline, and apparently, the development of these cells into endothelial cells is a nitric oxide dependent pathway [6].

Another study by Asahara found that these endothelial progenitor cells that had surface receptors Flk-1+ or tie- 2 were involved in angiogenesis, part of a generalized mechanism of stem cells' recruitment to areas of ischemic damage or where blood vessels regeneration is needed [10].

\section{Characterizing endothelial progenitor cells}

What is the real endothelial stem cell? That question is still in debate, and it depends on the location of the cells and their maturation and differentiation. These cells defined as early or young endothelial cells or endothelial progenitor cells were found in patients with sickle cell anemia [11], in septic shock [12], and in systemic lupus erythematosus [13]. The paradigm is that these cells are endothelial cells that died and are shed in the blood stream, but still, it is not clear enough and it could be that they are shed from the bone marrow [14-16]. In order to explore this enigma peripheral cells of patients who had bone marrow transplantation from a different gender (from male to female or vis versa) were studied, and it was found that 9 days after transplantation the endothelial cells were phenotypically cells of the recipient, which

Correspondence to: Arnon Blum, Baruch Padeh Poria Medical Center, Faculty of Medicine Bar Ilan University, Lower Galilee 15208, Israel; E-mail: Ablum@poria.health.gov.il

Received: January 20, 2016; Accepted: February 04, 2016; Published: February 08,2016 
means that those endothelial cells belonged to the recipient's blood vessels [17]. However, colonies of endothelial cells that appeared later on had phenotypic characteristics of the donor, and they had the ability to proliferate 1000 fold in 27 days, while early growth cells could not proliferate in the same rate. The other explanation is that we may find several kinds of young early endothelial cells in the peripheral blood, some of them originate in the bone marrow and others from the endothelium of the peripheral blood vessels. In order to distinguish between the different kinds of cells we have to use functional markers like growth in culture and the morphology of the colony in order to distinguish between the origins of these 2 groups of cells that we find in the peripheral blood $[18,19]$.

The general consensus is that most of the regenerative cells that build new blood vessels and repair damaged ones originate from the bone marrow and most of them ( $>90 \%)$ express markers of vascular endothelial growth factor receptor (VEGFR-2), CD34, and CD45 - a marker that characterizes mature endothelial cells [20], and 7 days in culture (fibronectin plated plates) markers of von Willebrand Factor appeared [21]. With time, it has become evident that CD34 ${ }^{+} /$ VEGFR-2 ${ }^{+}$cells behave like a population of cells that are defined as endothelial stem cells. However, many mature endothelial cells possess both markers on their cell's surface, and there was a need to refine the definition. Another marker of stem cells is CD133, a glycoprotein that its function is not completely clear, but defines hematopoietic stem cells with pluripotency ability to differentiate into different kind of cells [22]. CD133 is expressed solely on stem cells and not on mature cells [23], and it has been shown that cells that express both $\mathrm{CD} 34^{+} / \mathrm{CD} 133^{+}$ proliferate and create colonies of endothelial cells [23-25]. Another population of cells are defined by CD $34^{+} / \mathrm{VEGFR}-2^{+} / \mathrm{CD} 133^{-}$and they a limited ability to differentiate and become mature endothelial cells (Figure 1) [26].

\section{Endothelial progenitor cells' mobilization}

In order to be efficient, stem cells must have the ability to mobilize smoothly and quickly to areas of need. Vascular endothelial growth factor (VEGF) is one of the potent forces that are involved in mobilization and directing cells to areas of regeneration. In areas of ischemic or in malignant tumors VEGF expression is increasing exponentially $[27,28]$. Another potent peptide that is involved in mobilization is the Hypoxia Inducible Factor (HIF-1) [29-33]. Growth factors like Granulocyte Macrophage Colony Stimulating Factor (GMCSF) also contributes to stem cells mobilization together with VEGF during acute vascular events and acute stress $[34,35]$.

Estrogen has a positive effect on vasculogenesis by mobilization stem cells from the bone marrow. Mice that were injected estrogen their endothelium was regenerated faster and more effectively [36,37]. The effect of estrogen is through nitric oxide dependent pathways by activating the enzyme endothelial nitric oxide synthase - and appears that this enzyme has a key role in activating and mobilizing stem cells from the bone marrow [36,38].

Statins (HMG-CoA reductase inhibitors) have been shown to increase level of endothelial progenitor cells in the peripheral blood and in regeneration of blood vessels [39,40]. Patients with coronary artery disease have low level of endothelial progenitor cells marked as CD $34^{+} /$VEGFR $-2^{+}$and treating these patients with statins increased significantly (doubled) their level after 7 days of treatment [41].

There are medications that block angiogenesis, like angiostatin and endostatin - that block blood vessels' regeneration [42]. There are some ideas how to detach stem cells from their niches, like using chemokine receptor number 4 (CXCR4) inhibitor (Blum et al. Cytotherapy 2009) or activating metalloproteinases that break the bridges between the cells and the connective tissue $[43,44]$.

It is known that diabetes mellitus (DM) is a dominant involvement of the cardiovascular system. Impaired angiogenesis, oxidative stress, and inflammation are all possible confounders to the complexity of DM and its cardiovascular complications. Oxidative stress is considered a critical factor in endothelial progenitor cells' dysfunction. It was

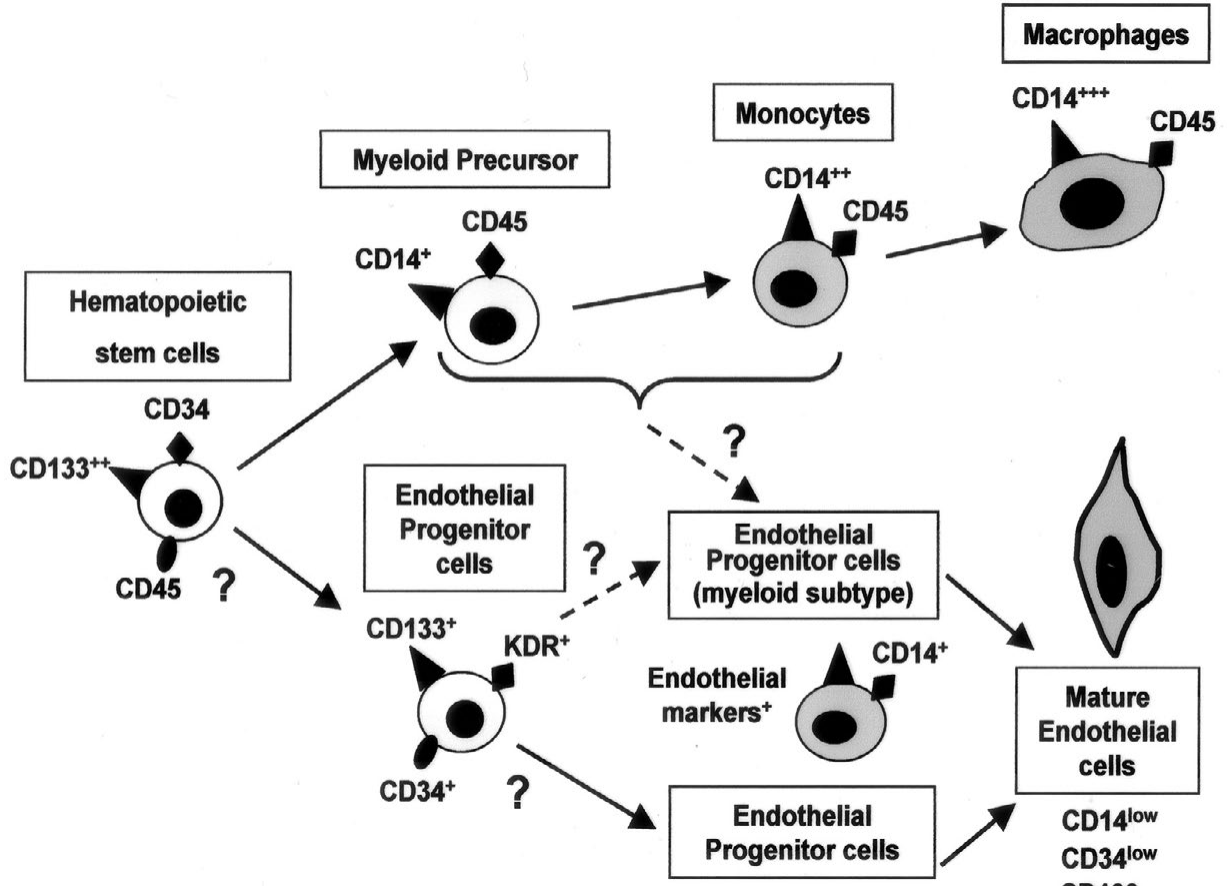

Figure 1. The development of the Endothelial Progenitor Cell from hematopoietic stem cells. 
found that high mobility group box-1 (HMGB-1) was upregulated in in serum and bone marrow in diabetic mice. Advanced glycation and productions (AGEs) induced expression of HMGB-1 in EPCs. Inhibition of the oxidative stress with $\mathrm{N}$-acetylcysteine (NAC) inhibited HMGB-1 induced by AGEs. HMGB-1 may play an important role in diabetes induced oxidative stress in EPCs and may be an important part of the mechanistic pathway that leads to cardiovascular disease in DM [45].

\section{Endothelial progenitor cells and cancer}

Studies have shown that endothelial progenitor cells are activated and are involved in angiogenesis and vasculogenesis in cancer, mainly in the stage of sending metastases. The belief is that this process takes place before we can document clinical invasion to remote places (metastases) [46-50]. There are 2 theories on that subject - one theory claims that these endothelial progenitor cells invade the endothelial cells of the tumor itself, and the other, that these cells invade the area around the tumor and secrete peptides and growth factors that encourage angiogenesis. For example, granulocyte colony stimulating factor (G-CSF) upregulates vasculogenesis and angiogenesis, and at the same time has been shown to enhance the cancerous process [51]. Cancerous cells proliferation is dependent on blood vessels' supply and knockout mice without the Id peptides can't grow cancer tumors in their bodies because of lack of vascular supply [52]. These knockout mice survived longer than mice without this genetic change [53]. On the other hand, when stem cells were injected from healthy donors (healthy mice) to these knockout mice it improved vessels' growth and the cancer cells started to proliferate in the same rate as normal mice [53].

Radiation therapy during childhood cancer treatment increases the likelihood to develop cardiovascular disease in adulthood. EPCs may be affected by radiation and may affect future vascular outcome. A study by Pradhan et al. has demonstrated that endothelial colony forming cells (ECFCs) and circulating endothelial cells (CECs) were both inhibited among survivors of childhood cancer with radiation therapy. It was suggested that ECFCs could be biomarkers of vascular injury and may help to identify survivors at risk for adulthood cardiovascular disease [54].

\section{Endothelial progenitor cells in cardiovascular diseases}

Endothelial progenitor cells were penetrated the endothelium of blood vessels surrounding the infarct zone in the myocardium [55]. Athymic rats that had myocardial infarction were implanted human CD34+ cells that were treated before transplantation with G-CSF developed much more vasculature around the infarct zone, much more than rats that were not transplanted with these cells [16]. Human endothelial cells were detected within the infarct zone of the rat and that is a proof to the ability of transplanted cells to be involved in vasculogenesis post myocardial infarction. It was also found that the apoptosis in the infarct zone was significantly diminished in rats that were transplanted CD34+ cells [16].

\section{Endothelial progenitor cells in regeneration of blood vessels}

Atherosclerosis is a degenerative process that leads to endothelial damage and dysfunction. It is a long standing process that is accelerated and aggravated in conditions like hypertension, smoking, hyperlipidemia, ageing and in postmenopausal women. These processes cause chronic inflammation, endothelial damage and dysfunction, and atherosclerotic plaques [55]. In parallel free oxygen radicals cause apoptosis which accelerates even more the atherosclerotic process [56-58]. In the past it was believed that the regeneration process and "damage control" was handled by resident cells so that the next-door cells secreted factors that "treated" the damaged endothelium and supplied the necessary supplies for regeneration [59]. Now it has been proved that regeneration of damaged endothelial cells is conducted by endothelial stem cells that originate from the bone marrow's niches and from resident stem cells (stem cells that reside in the vascular bed and are located within the vessel wall) [60]. Healthy rodents that were treated with statins had a faster repair of damaged endothelium, and the stem cells number in the circulation of these rodents that were treated with statins was significantly elevated. The stem cells of rodents that were treated with statins were more potent and responded more vigorously to ischemia, and tended to reach damaged endothelium faster and more appropriately [61,62].

Apo E-/- mice are used as a model for aggressive atherosclerosis. When endothelial progenitor cells were injected to these knockout mice their atherosclerosis was less aggressive compared to the control animals [63]. No change was observed in cholesterol level but the rate of endothelial cells regeneration was significantly faster.

Age is also affecting the functional ability to regenerate and repair damaged blood vessels. Endothelial progenitor cells taken from young Apo E-/- mice were more potent and had a better ability to regenerate damaged endothelium than stem cells taken from old Apo E-/- mice. The telomeres of the intima cells of Apo E-/- mice were longer when they were transplanted endothelial progenitor cells from young mice another proof that supports previous studies that found an association between aging and the endothelium, aging and endothelial dysfunction and aging and atherosclerosis [64]. These studies teach us about the importance of endothelial stem cells in vascular regeneration and the general phenomenon of aging - older animals are more prone to develop atherosclerosis because an impairment in their endothelial progenitor stem cells' function.

In humans, subjects with conditions that lead to atherosclerosis (like diabetes mellitus or hypercholesterolemia) have less endothelial progenitor cells and their function is impaired [65-68]. In healthy human subjects there is an inverse correlation between the risk of death (the Framingham score) and the ability to build colonies of endothelial progenitor stem cells in culture from the peripheral blood [19]. Levels of the endothelial progenitor cells in the peripheral blood predicted vascular reactivity - an expression of endothelial function, and could predict better than the traditional risk factors the risk of future cardiovascular events and death [19]. These cells taken from patients with cardiovascular risk factors demonstrated accelerated senescence and higher rate of apoptosis [19]. One of the hypotheses is that there is a certain limit to the bone marrow to produce and mobilize stem cells in extreme conditions, and after a certain stage there is a general state of exhaustion of the bone marrow without any more ability to produce and mobilize these cells to areas of need. This theory is supported by studies in an animal model (Apo E-/- mice) that had smaller numbers of endothelial progenitor cells with an impaired function - a progressive condition that aggravated with time $[63,64]$.

Preservation of the vascular endothelium is also kept by endothelial progenitor cells. These cells have been shown to incorporate into regenerated endothelium of damaged blood vessels [69] incorporating into small vessels of the implanted organ with regeneration of new blood vessels in the transplanted organ [70,71]. 
Human studies demonstrated that patients with recurrent restenosis of the coronary arteries had lower numbers of endothelial stem cells compared with patients who did not have recurrent stenosis and had fewer events of restenosis [72,73].

Exosomes, a key component in paracrine secretion may have a protective effect in vascular disease. Recently Li et al. [74] found that EPC-derived exosomes accelerated re-endothelialization after endothelial damage in a rat carotid artery. They also improved migration and proliferation of endothelial cells and may enhance vascular repair following endothelial injury [74].

\section{Stem cells' transplantation in acute myocardial infarction (AMI)}

Several human clinical trials have transplanted endothelial progenitor cells into the myocardium by injecting the cells into the coronary circulation during an acute myocardial infarction Transplantation of progenitor cells and regeneration enhancement in acute myocardial infarction (TOPCARE-AMI) [75-77], that have demonstrated improved ejection fraction of $6 \%$ to $9 \%$, with a reduction in end systolic diameter 6 months post transplantation. These studies have demonstrated that an autologous stem cells injection into the coronary arteries is a safe and a feasible procedure in patients with an acute myocardial infarction in the acute phase and enables improved function of the heart and of the patient's functional score. The functional improvement resulted from improved function of the area in the myocardium that was damaged during the myocardial infarction.

In another clinical study endothelial progenitor cells were injected twice after an AMI - Reinfusion of Enriched Progenitor Cells And Infarct Remodeling in Acute Myocardial Infarction (REPAIR-AMI) [79] - and a significant improvement was found in ejection fraction, in lowering recurrent ischemic events, in re-infarction, and in the need for re-vascularization in patients who had stem cells transplantation compared to the non-transplanted patients even 1 year after the AMI and the transplantation. The patients who gained the most were those with lower than $48.9 \%$ ejection fraction. These patients had the most significant improvement in ejection fraction of the left ventricle and in clinical hemodynamic parameters. It means that more clinically severe patients gain more from this procedure.

A study that compared between 2 kind of cells - autologous whole white blood cells of bone marrow and endothelial progenitor cells from the peripheral blood -transplanted into the coronary arteries 4 days after opening an artery during an acute myocardial infarction (primary PCI) - found no difference in improvement in left ventricular ejection fraction 4 and 12 months post AMI (TOPCARE study) [80]. Another study where autologous whole white blood cells or endothelial progenitor cells were injected 3 months post AMI into the coronary system - found a better response to the autologous whole white cells of the bone marrow in improving the left ventricular ejection fraction [76].

A meta-analysis of 18 clinical stem cells transplantation trials (cell transplantation to the heart) that included 999 patients found that left ventricular ejection fraction was improved with a reduction of end systolic diameter [78]. Objective parameters were improved much better than the conventional treatment and an MRI follow up study of these patients found that the scar tissue was significantly smaller and in general, the end diastolic volume of the left ventricle was smaller with an improved regional contraction in the scar zone and in the function of the left ventricle [78].
Timing of transplantation is another issue - with no definite conclusions - but the REPAIR-AMI study found no improvement in ejection fraction and other parameters in patients transplanted up to 4 days post AMI, but a later transplantation (between days 4 and 8 post AMI) showed a better ejection fraction of the left ventricle [79].

A human study found that age and coronary artery disease impaired the function of circulating angiogenic cells (CACs) [80]. CACs are peripheral blood cells whose functional capacity was found to inversely correlate with cardiovascular risk. Chen et al. found that transduction of endothelial nitric oxide synthase (eNOS) gene cDNA adenovirus increased nitric oxide production, migration, and cardiac function of post myocardial infarction mice implanted with CACs. This finding is especially important for improving the efficiency of older donors, and eNOS gene therapy in CACs from old donors to patients with coronary artery disease may improve autologous cell therapy outcome [80].

\section{Stem cells transplantation in unstable angina pectoris}

Intra-myocardial injection of $\mathrm{CD}^{+} 4^{+}$cells was performed in 167 patients with severe unstable angina pectoris using endocardial electromagnetic mapping system (ACT-45CMI study) [80]. Following the transplantation there was a decrease in the frequency of chest pain within 6 and 12 months with a significant improvement in exercise ability and a significant decrease in mortality. In another group of 24 patients with unstable angina pectoris $\mathrm{CD} 34^{+}$cells were injected after an upgrade of the cells with G-CSF in vitro. Patients who got the cells had a decrease in the frequency of their chest pain - in the intensity and frequency - with a decrease in the use of nitroglycerin and a better exercise performance compared to patients who got placebo [81]. In another study CD34 ${ }^{+}$cells were injected through the coronaries to 112 patients with severe unstable angina pectoris and this treatment helped to improve clinical chest pain and exercise time [82].

In another study with 28 patients with severe stable angina pectoris who had no further optional treatment 1 or 2 million cells (autologous) were injected to the myocardium in a placebo controlled study. It was found that all patients that were treated with cells responded with a better clinical angina syndrome, improved their quality of life, and in the exercise tolerance [83]. More studies support these findings $[80,84-86]$, but it seems now that the injection approach and method are important for the success of the intervention. The most reliable and effective approach is intra-myocardial injection of cells guided by the NOGA system [NOGA-XP Cardiac Navigation System (Biologics Delivery Systems Group of Cordis Corporation, a Johnson \& Johnson company; Irwindale, Calif)] [81].

\section{Summary}

"Stem cells therapy is the new generation antibiotics"...the regenerative medicine and stem cells transplantation has become one of the most promising and fascinating field in medicine with a lot of hope and promises.

In cardiovascular medicine stem cells transplantation seems to be a very attractive alternative to the present management of patients with heart disease and heart failure, and also in prevention of atherosclerosis.

\section{References}

1. Folkman J, Shing J (1992) Angiogenesis. Adv Exp Med Biol 313: 355-364. [Crossref]

2. Risau W, Sariola H, Zerwes HG, Sasse J, Ekblom P, et al. (1988) Vasculogenesis and angiogenesis in embryonic-stem cell-derived embryoid bodies. Development 102: 471478. [Crossref] 
3. Flamme I, Risau W (1992) Induction of vasculogenesis and hematopoiesis in vitro. Development. 116: 435-439. [Crossref]

4. Weiss MJ, Orkin SH (1996) In vitro differentiation of murine embryonic stem cells. New approaches to old problems. J Clinical Invest 97: 591-595. [Crossref]

5. Brugger W, Heimfeld S, Berenson RJ, Mertelsmann R, Kanz L (1995) Reconstitution of hematopoiesis after high-dose chemotherapy by autologous progenitor cells generated ex vivo. $N$ England J Med 333: 283-287. [Crossref]

6. Asahara T, Murohara T, Sullivan A, Silver M, van der Zee R, et al. (1997) Isolation of putative endothelial cells for angiogenesis. Science 275: 964-967. [Crossref]

7. Civin CI, Strauss LC, Brovall C, Fackler MJ, Schwartz JF, et al. (1984) Antigenic analysis of hematopoiesis. III. A hematopoietic progenitor cell surface antigen defined by a monoclonal antibody against KG-1 a cells. J Immunology 133: 157-165. [Crossref]

8. Matthews W, Jordan CT, Gavin M, Jenkins NA, Copeland NG, et al. (1991) A receptor tyrosine kinase cDNA isolated from a population of enriched primitive hematopoietic cells and exhibiting close genetic linkage to c-kit. Proc Natl Academy Science U S A. 88: 9026-9030. [Crossref]

9. Newman PJ, Berndt MC, Gorski J, White GC 2nd, Lyman S, et al. (1990) PECAM-1 (CD31) cloning and relation to adhesion molecules of the immunoglobulin gene superfamily. Science 247: 1219-1222. [Crossref]

10. Asahara T, Masuda H, Takahashi T, Kalka C, Pastore C, et al. (1999) Bone marrow origin of endothelial progenitor cells responsible for postnatal vasculogenesis in physiological and pathological neovascularization. Circulation Res 85: 221-228. [Crossref]

11. Solovey A, Lin Y, Browne P, Choong S, Wayner E, et al. (1997) Circulating activated endothelial cells in sickle cell anemia. NEJM 337: 1584-1590. [Crossref]

12. Mutunga M, Fulton B, Bullock R, Batchelor A, Gascoigne A, et al. (2001) Circulating endothelial cells in patients with septic shock. American J Respiratory Critical Care Med 163: 195-200. [Crossref]

13. Clancy R, Marder G, Martin V, Belmont HM, Abramson SB, et al. (2001) Circulating activated endothelial cells in systemic lupus erythematosus: further evidence for diffuse vasculopathy. Arthritis Rheum 44: 1203-1208. [Crossref]

14. Segal MS, Bihorac A, Koc M (2002) Circulating endothelial cells: tea leaves for renal disease. Am J Physiology Renal Physiology 283: F11-19. [Crossref]

15. Kalka C, Masuda H, Takahashi T, Kalka-Moll WM, Silver M, et al. (2000) Transplantation of ex vivo expanded endothelial progenitor cells for therapeutic neovascularization. Proc Natl Academy Science USA 97: 3422-3427. [Crossref]

16. Kocher AA, Schuster MD, Szabolcs MJ, Takuma S, Burkhoff D, et al. (2001) Neovascularization of ischemic myocardium by human bone marrow derived angioblasts prevents cardiomyocyte apoptosis, reduces remodeling and improves cardiac function. Nat Med 7: 430-436. [Crossref]

17. Lin Y, Weisdorf DJ, Solovey A, Hebbel RP (2000) Origins of circulating endothelial cells and endothelial outgrowth from blood. J Clinical Invest 105: 71-77. [Crossref]

18. Shi Q, Rafii S, Wu MH, Wijelath ES, Yu C, et al. (1998) Evidence for circulating bone marrow derived endothelial cells. Blood 92: 362-367. [Crossref]

19. Hill JM, Zalos G, Halcox JP, Schenke WH, Waclawiw MA, et al. (2003) Circulating endothelial progenitor cells, vascular function, and cardiovascular risk. NEJM 348: 593-600. [Crossref]

20. Kreipe H, Radzun HJ, Schumacher U, Parwaresch MR (1986) Lectine binding and surface glycoprotein pattern of human macrophage populations. Histochemistry 86: 201-206. [Crossref]

21. Khakoo AY, Finkel T (2005) Endothelial progenitor cells. Annual Rev Med 56: 79-101. [Crossref]

22. Yin AH, Miraglia S, Zanjani ED, Almeida-Porada G, Ogawa M, et al. (1997) AC133, a novel marker for human hematopoietic stem and progenitor cells. Blood 90: 50025012. [Crossref]

23. Peichev M, Naiyer AJ, Pereira D, Zhu Z, Lane WJ, et al. (2000) Expression of VEGFR-2 and AC133 by circulating human CD34+ cells identifies a population of funtional endothelial precursors. Blood 95: 952-958. [Crossref]

24. Quirici N, Soligo D, Caneva L, Servida F, Bossolasco P, et al. (2001) Differentiation and expansion of endothelial cells from human bone marrow CD133+ cells. $\mathrm{Br} J$ Haematol 115: 186-194. [Crossref]

25. Gehling UM, Ergün S, Schumacher U, Wagener C, Pantel K, et al. (2000) In vitro differentiation of endothelial cells from AC133 positive progenitor cells. Blood 95: 3106-3112. [Crossref]

26. Hur J, Yoon CH, Kim HS, Choi JH, Kang HJ, et al. (2004) Characterization of two types of endothelial progenitor cells and their different contributions to neovasculogenesis. Arterioscler Thromb Vasc Biol 24: 288-293. [Crossref]

27. Banai S, Shweiki D, Pinson A, Chandra M, Lazarovici G, et al. (1994) Upregulation of vascular endothelial growth factor expression induced by myocardial ischemia implications for coronary angiogenesis. Cardiovascular Res 28: 1176-1179. [Crossref]

28. Carmeliet P, Jain RK (2000) Angiogenesis in cancer and other diseases. Nature 407 249-257. [Crossref]

29. Risau W (1997) mechanisms of angiogenesis. Nature 386: 671-674. [Crossref]

30. Shweiki D, Itin A, Soffer D, Keshet E (1992) Vascular endothelial growth factor induced by hypoxia may mediate hypoxia initiated angiogenesis. Nature 359: 843-845. [Crossref]

31. Asahara T, Takahashi T, Masuda H, Kalka C, Chen D, et al. (1999) VEGF contributes to postnatal neovascularization by mobilizing bone marrow derived endothelial progenitor cells. EMBOJ 18: 3964-3972. [Crossref]

32. Kalka C, Tehrani H, Laudenberg B, Vale PR, Isner JM, et al. (2001) VEGF gene transfer mobilizes endothelial progenitor cells in patients inoperable coronary disease. Ann NY Academy of Science 938: 36-45. [Crossref]

33. Moore MA, Hattori K, Heissig B, Shieh JH, Dias S, et al. (2001) Mobilization of endothelial and hematopoietic stem and progenitor cells by adeno-vector-mediated elevation of serum levels of SDF-, VEGF, and angiopoietin-1. Ann NY Academy Science 938: 36-45. [Crossref]

34. Gill M, Dias S, Hattori K, Rivera ML, Hicklin D, et al. (2001) Vascular trauma induces rapid but transient mobilization of VEGFR2+ AC133+ endothelial precursor cells. Circulation Res 88: 167-174. [Crossref]

35. Takahashi T, Kalka C, Masuda H, Chen D, Silver M, et al. (1999) Ischemia and cytokine induced mobilization of bone marrow derived endothelial progenitor cells for neovascularization. Nat Med 5: 434-438. [Crossref]

36. Iwakura A, Luedemann C, Shastry S, Hanley A, Kearney M, et al. (2003) Estrogen mediated, endothelial nitric oxide synthase dependent mobilization of bone marrow derived endothelial progenitor cells contributes to re-endothelialization after arterial injury. Circulation 108: 3115-3121. [Crossref]

37. Strehlow K, Werner N, Berweiler J, Link A, Dirnagl U, et al. (2003) Estrogen increases bone marrow derived endothelial progenitor cell production and diminishes neointimal formation. Circulation 107: 3059-3065. [Crossref]

38. Aicher A, Heeschen C, Mildner-Rihm C, Urbich C, Ihling C, et al. (2003) Essential role of endothelial nitric oxide synthase for mobilization of stem and progenitor cells. Nat Med 9: 1370-1376. [Crossref]

39. Shepherd J, Cobbe SM, Ford I, Isles CG, Lorimer AR, et al. (1995) Prevention of coronary heart disease with pravastatin in men with hypercholesterolemia. West of Scotland Coronary Prevention Study Group. NEJM 333: 1301-1307. [Crossref]

40. Llevadot J, Murasawa S, Kureishi Y, Uchida S, Masuda H, et al. (2001) HMG-CoA reductase inhibitor mobilizes bone marrow derived endothelial progenitor cells. JCI 108: 399-405. [Crossref]

41. Vasa M, Fichtlscherer S, Adler K, Aicher A, Martin H, et al. (2001) Increase in circulating endothelial progenitor cells by statin therapy in patients with stable coronary artery disease. Circulation 103: 2885-2890. [Crossref]

42. Ito H, Rovira II, Bloom ML, Takeda K, Ferrans VJ, et al. (1999) Endothelial progenitor cells as putative targets for angiostatin. Cancer Res 59: 5875-5877. [Crossref]

43. Kollet O, Shivtiel S, Chen YQ, Suriawinata J, Thung SN, et al. (2003) HGF, SDF-, and MMP-9 are involved in stress induced human CD34+ stem cell recruitment to the liver. JCI 112: 160-169. [Crossref]

44. Heissig B, Hattori K, Dias S, Friedrich M, Ferris B, et al. (2002) Recruitment of stem and progenitor cells from the bone marrow niche requires MMP-9 mediated release of kit-ligand. Cell 109: 625-637. [Crossref] 
45. Wu H, Li R, Wei ZH, Zhang XL, Chen JZ, et al. (2016) Diabetes induced oxidative stress in endothelial progenitor cells may be sustained by a positive feedback loop involving high mobility group box-1. Oxidative Medicine and Cellular Longevity 1943918.

46. Davidoff AM, Ng CY, Brown P, Leary MA, Spurbeck WW, et al. (2001) Bone marrow derived cells contribute to tumor neovasculature and, when modified to express an angiogenesis inhibitor, can restrict tumor growth in mice. Clinical Cancer Res 7: 28702879. [Crossref]

47. Moore XL, Lu J, Sun L, Zhu CJ, Tan P, et al. (2004) Endothelial progenitor cells' "homing" specificity to brain tumors. Gene Therapy 11: 811-818. [Crossref]

48. de Bont ES, Guikema JE, Scherpen F, Meeuwsen T, Kamps WA, et al. (2001) Mobilized human CD34+ hematopoietic stem cells enhance tumor growth in a non-obese diabetic/ severe combined immune-deficient mouse model of human non-Hodgkin's lymphoma. Cancer Res 61: 7654-7659. [Crossref]

49. Garcia-Barros M, Paris F, Cordon-Cardo C, Lyden D, Rafii S, et al. (2003) Tumor response to radiotherapy regulated by endothelial cell apoptosis. Science 300: 11551159. [Crossref]

50. Natori T, Sata M, Washida M, Hirata Y, Nagai R, et al. (2002) G-CSF stimulates angiogenesis and promotes tumor growth: potential contribution of bone marrow derived endothelial progenitor cells. Biochem Biophys Res Commun 297: 1058-1061. [Crossref]

51. Benezra R, Rafii S, Lyden D (2001) The Id proteins and angiogenesis. Oncogene 20: 8334-8341. [Crossref]

52. Lyden D, Hattori K, Dias S, Costa C, Blaikie P, et al. (2001) Impaired recruitment of bone marrow derived endothelial and hematopoietic precursor cells blocks tumor angiogenesis and growth. Nat Med 7: 1194-1201. [Crossref]

53. Zhang ZG, Zhang L, Jiang Q, Chopp M, et al. (2002) Bone marrow derived endothelial progenitor cells participate in cerebral neovascularization after focal cerebral ischemia in the adult mouse. Circulation Res 90: 284-288. [Crossref]

54. Pradhan K, Mund J, Case J, Gupta S, liu Z, et al. (2015) Differences in circulating endothelial progenitor cells among childhood cancer survivors treated with and without radiation. J Hematol Thromb 1: 4. [Crossref]

55. Askari AT, Unzek S, Popovic ZB, Goldman CK, Forudi F, et al. (2003) Effect of stromal cell derived factor 1 on stem cell homing and tissue regeneration in ischemic cardiomyopathy. Lancet 362: 697-703. [Crossref]

56. Lusis AJ (2000) Atherosclerosis. Nature 407: 233-241. [Crossref]

57. Dimmeler S, Haendeler J, Zeiher AM (2002) Regulation of endothelial cell apoptosis in atherothrombosis. Current Opinion Lipidology 13: 531-536. [Crossref]

58. Dimmeler S, Rippmann V, Weiland U, Haendeler J, Zeiher AM (1997) Angiotensin II induces apoptosis of human endothelial cells. Protective effect of nitric oxide. Circulation Res 81: 970-976. [Crossref]

59. Dimmeler S, Haendeler J, Galle J, Zeiher AM (1997) Oxidized low density lipoprotein induces apoptosis of human endothelial cells by activation of CPP32-like proteases. A mechanistic clue to the "response to injury" hypothesis. Circulation 95: 1760-1763. [Crossref]

60. Gotlieb AI, Lee TY (1999) Endothelial repair in atherosclerosis. Curr Top Pathol 93 157-166. [Crossref]

61. Walter DH, Rittig K, Bahlmann FH, Kirchmair R, Silver M, et al. (2002) Statin therapy accelerates re-endothelialization: a novel effect involving mobilization and incorporation of bone marrow derived endothelial progenitor cells. Circulation 105: 3017-3024. [Crossref]

62. Werner N, Priller J, Laufs U, Endres M, Böhm M, et al. (2002) Bone marrow derived progenitor cells modulate vascular re endothelialization and neo-intimal formation: effect of 3-hydroxy-3-methylglutaryl coenzyme A reductase inhibition. Artherioscler Thrombosis \& Vascular Biology 22: 1567-1572. [Crossref]

63. Rauscher FM, Goldschmidt-Clermont PJ, Davis BH, Wang T, Gregg D, et al. (2003) Aging, progenitor cell exhaustion, and atherosclerosis. Circulation 108: 457-463. [Crossref]

64. Minamino T, Miyauchi H, Yoshida T, Ishida Y, Yoshida H, et al. (2002) Endothelial cell senescence in human atherosclerosis: role of telomere in endothelial dysfunction. Circulation 105: 1541-1544. [Crossref]
65. Heeschen C, Lehmann R, Honold J, Assmus B, Aicher A, Walter DH, et al. (2004) Profoundly reduced neovascularization capacity of bone marrow mononuclear cells derived from patients with chronic ischemic heart disease. Circulation 109: 1615-1622. [Crossref]

66. Tepper OM, Galiano RD, Capla JM, Kalka C, Gagne PJ, et al. (2002) Human endothelial progenitor cells from type II diabetic patients exhibit impaired proliferation, adhesion, and incorporation into vascular structures. Circulation 106: 2781-2786. [Crossref]

67. Vasa M, Fichtlscherer S, Aicher A, Adler K, Urbich C, et al. (2001) Number and migratory activity of circulating endothelial progenitor cells inversely correlate with risk factors for coronary artery disease. Circ Res 89: e1-7. [Crossref]

68. Eizawa T, Murakami Y, Matsui K, Takahashi M, Muroi K, et al. (2003) Circulating endothelial progenitor cells are reduced in hemodialysis patients. Curr Med Res Opin 19: 627-633. [Crossref]

69. Xu Q, Zhang Z, Davison F, Hu Y (2003) Circulating progenitor cells regenerate endothelium of vein graft atherosclerosis, which is diminished in ApoE-deficient mice. Circ Res 93: e76-86. [Crossref]

70. Hillebrands JL, Klatter FA, van Dijk WD, Rozing J (2002) Bone marrow does not contribute substantially to endothelial cell replacement in transplant arteriosclerosis. Nat Med 8: 194-195. [Crossref]

71. Simper D, Wang S, Deb A, Holmes D, McGregor C, et al. (2003) Endothelial progenitor cells are decreased in blood of cardiac allograft patients with vasculopathy and endothelial cells of non-cardiac origin are enriched in transplant atherosclerosis Circulation 108: 143-149. [Crossref]

72. Bauters C, Isner JM (1997) The biology of restenosis. Prog Cardiovasc Dis 1997; 40: 107-116. [Crossref]

73. George J, Herz I, Goldstein E, Abashidze S, Deutch V, et al. (2003) Number and adhesive properties of circulating endothelial progenitor cells in patients with in stent restenosis. Arterioscler Thromb Vasc Biol 23: e57-60. [Crossref]

74. Li X, Chen C, Wei L, Li Q, Niu X, et al. (2016) Exosomes derived from endothelia progenitor cells attenuate vascular repair and accelerate reendothelialization by enhancing endothelial function. Cytotherpay 18: 253-262. [Crossref]

75. Strauer BE, Brehm M, Zeus T, Köstering M, Hernandez A, et al. (2002) Repair of infarcted myocardium by autologous intracoronary mononuclear bone marrow cell transplantation in humans. Circulation 106: 1913-1918. [Crossref]

76. Assmus B, Honold J, Schächinger V, Britten MB, Fischer-Rasokat U, et al. (2006) Transcoronary transplantation of progenitor cells after myocardial infarction. NEJM 355: 1222-1232. [Crossref]

77. Schächinger V, Assmus B, Britten MB, Honold J, Lehmann R, et al. (2004) Transplantation of progenitor cells and regeneration enhancement in acute myocardial infarction: final one year results of the TOPCARE-AMI trial. JACC 44: 1690-1699. [Crossref]

78. Abdel-Latif A, Bolli R, Tleyjeh IM, Montori VM, Perin EC, et al. (2007) Adult bone marrow derived cells for cardiac repair: a systemic review and meta-analysis. Arch Intern Med 167: 989-997. [Crossref]

79. Schuster MD, Kocher AA, Seki T, Martens TP, Xiang G, et al. (2004) Myocardia neovascularization by bone marrow angioblasts results in cardiomyocyte regeneration. Am J Physiol Heart Circ Physiol 287: H525-H532. [Crossref]

80. Losordo DW, Henry TD, Davidson C, Sup Lee J, Costa MA, et al. (2011) Intramyocardial, autologous CD34+ cell therapy for refractory angina. Circ Res 109: 428-436. [Crossref]

81. Losordo DW, Schatz RA, White CJ, Udelson JE, Veereshwarayya V, et al. (2007) Intramyocardial transplantation of autologous $\mathrm{CD} 34+$ stem cells for intractable angina: a phase I/Iia double blind, randomized controlled trial. Circulation 115: 3165-3172. [Crossref]

82. Wang S, Cui J, Peng W, Lu M (2010) Intracoronary autologous CD34+ stem cell therapy for intractable angina. Cardiology 117: 140-147. [Crossref]

83. Tse HF, Thambar S, Kwong YL, Rowlings P, Bellamy G, et al. (2007) Prospective randomized trial of direct endomyocardial implantation of bone marrow cells for treatment of severe coronary artery disease (PROTECT-CAD trial). Eur Heart $J 28$ : 2998-3005. [Crossref]

84. van Ramshorst J, Bax JJ, Beeres SL, Dibbets-Schneider P, Roes SD, et al. (2009) Intra- 
myocardial bone marrow cell injection for chronic myocardial ischemia: a randomized controlled trial. JAMA 301: 1997-2004. [Crossref]

85. Vicario J, Campo C, Piva J, Faccio F, Gerardo L, et al. (2005) One year follow up of trans-coronary sinus administration of autologous bone marrow in patients with chronic refractory angina. Cardiovasc Revasc Med 6: 99-107. [Crossref]

86. Schächinger V, Erbs S, Elsässer A, Haberbosch W, Hambrecht R, et al. (2006) Intracoronary bone marrow derived progenitor cells in acute myocardial infarction. NEJM 355: 1210-1221. [Crossref]

Copyright: (C2016 Blum A. This is an open-access article distributed under the terms of the Creative Commons Attribution License, which permits unrestricted use, distribution, and reproduction in any medium, provided the original author and source are credited. 